\title{
INTERVIEW WITH DEREK C. FORD
}

\author{
conducted by IVO LUČIĆ
}

\section{ACTA CARSOLOGICA INTERVIEW}

Several years ago, Ivo Lucić, a journalist and karstologist, suggested to make a series of interviews with some of the key figures of the $20^{\text {th }}$ century karstology. The Editorial Board was open to the idea, which soon came to realisation. We are more or less familiar with the scientific work of the interviwees, however their personal view on the field that they have contributed so much to, is also important and interesting to the community.

What brought them into the karst research? How do they see past, present and future development of karstology? Which were the main milestones and which are the main open question for future generations? These are only some of the topics that this series will cover.

A selection of the interviewees has not been easy and is not yet definite. The author has taken care for their topical and geographical diversity. There are many of those who we would like to hear from, but there is a limited space for it. However, we hope that the author will continue his work and that in a few years a unique archive of views to karstology will be compiled.

The series starts in this issue with professor Derek C. Ford, probably „the“ key figure in karst science of the last half-century. As a teacher, researcher, consultor and author he has contributed a lot to the world recognition of karst and research related to it.

Franci Gabrovšek Co-Editor

\section{DEREK C. FORD, \\ Professor Emeritus, McMaster University, Canada}

\section{PERSONAL AND BEGINNIG}

What was attracting you to karst? What had influenced you to select karst for all your life: childhood experiences, scientific interest or some important person from the karst world?

FORD: It was a mixture of these factors. As a schoolboy of twelve I began to bicycle $30 \mathrm{~km}$ from my home to the small gorge of Burrington Combe in the Mendip Hills, SW England. With friends I explored the little paleo-spring caves there and gradually moved up into the bigger caves on the top of the hills and around Cheddar Gorge. I was a strong explorer by the time I went to Oxford University for my undergraduate studies, and was also engaged in topographic mapping of caves. This led me to an increasing interest in their genesis. Marjorie Sweeting, the most prominent British cave scientist at the time, was teaching at Oxford and agreed to take me as her first $\mathrm{PhD}$ student when I had completed my BA Hons degree in geography in 1958. My wife and I emigrated to Canada the following year, where I began teaching at McMaster University, Hamilton, Ontario, but we returned to the Mendip Hills each summer for field studies in the caves. My investigations at the time were the most detailed to be attempted in caves and gave me the basis for my later general theory of meteoric (hy-

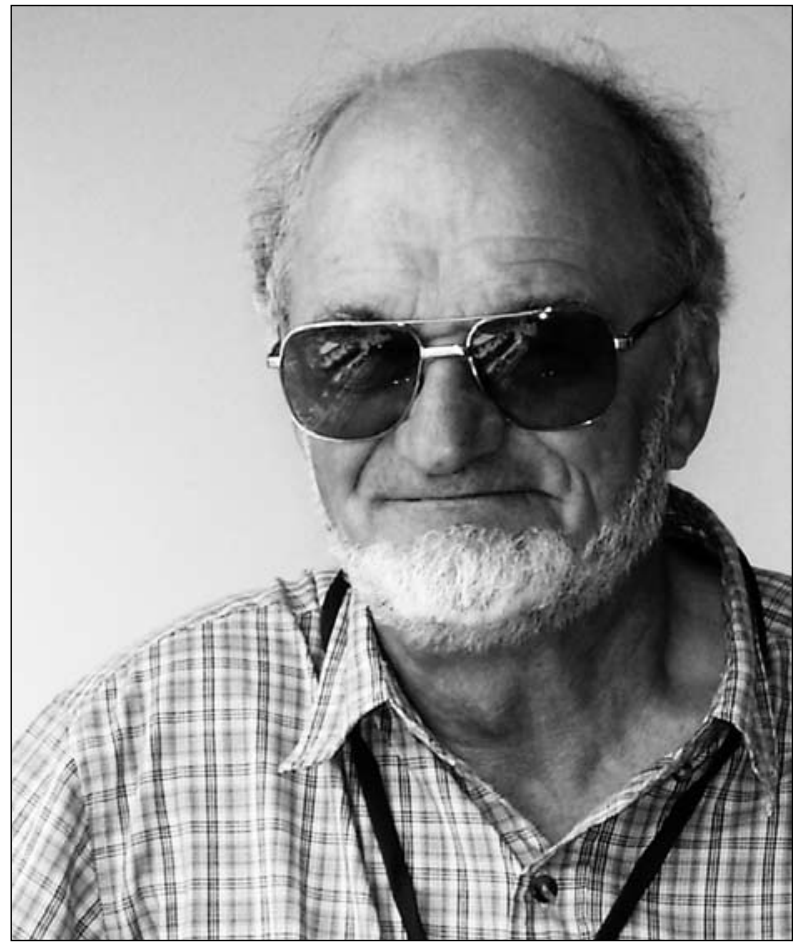

Derek Ford portrait from the UIS congress in Athens at 2005. (Photo: archive of D. Ford)

pergene) cave development. The thesis was completed and accepted in 1963. In 1964 I attended the quadrennial congress of the International Geographical Union 
in London where, at a field symposium, I first met Paul Williams and noted European karstologists such as Bögli, Corbel, H. Lehmann, Kramer, Roglić. This inspired me to broaden my interests to all karst phenomena.

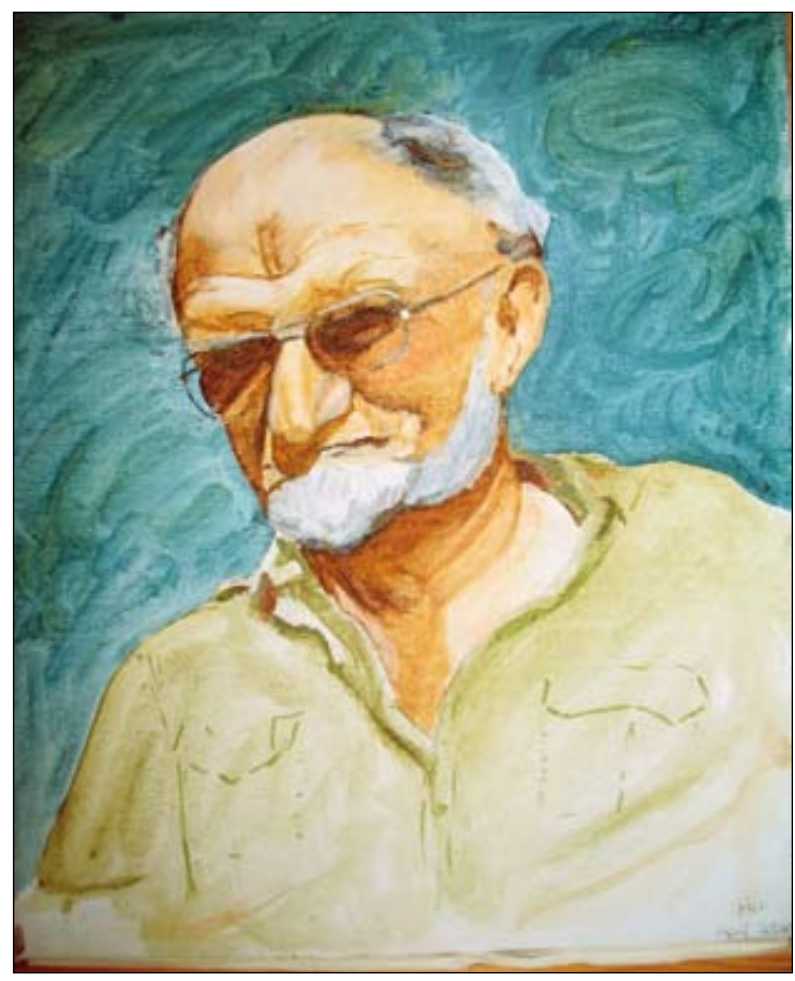

Oil painting of Derek Ford that his wife did for his birthday.

What was the perception of karst and karstology in the time you were at the doorstep of those phenomena. How did look like karstology world at that time, how many karstology centers were organized, what was their main interest?

FORD: Karst studies then were very much a subspecialty of geomorphology, qualitative and without firm foundations in scientific methods (despite the pioneer quantitative work of J Cvijić). The emphasis was upon effects of climate on surface karst landforms (tropical, temperate types, etc), which I considered to be over-interpreted. Quantitative dissolution studies were just beginning, much aided by the recent development of the Schwarczenbach EDTA titration method.

There were no strong karst research institutes in the western world, just individuals or very small groups without much money. We knew little of the work being done in eastern Europe and the Soviet Union. China was a complete blank!

How much were research conditions developed at that time and how did you felt as karstology researcher in comparison with colleagues of others (geographic, geologic...) disciplines?
FORD: As noted, the research was comparatively simple, mostly qualitative. There was little or no co-ordination with geologists, who knew about the rocks but paid little heed to the landforms or caves in them. The research was mainly by geographers and lacked any national or international co-ordination of goals until an 'International Karst Atlas' was decided as a venture of a new Commission of the IGU in 1964. The initial focus of this atlas was to illustrate the different climatic types of karst landscapes which are found; because of the major effects of differing lithology and structure from place to place, it never succeeded in producing a coherent body of examples, in my opinion.

\section{KARSTOLOGY DEVELOPMENT}

Which phases you see in karstology science development and which happening do you see as milestone for it?

FORD: In the 1960s and 1970s the geography-based subject became much more scientifically founded in the English-speaking world. This was partly due to the 'Quantitative Revolution' (so-called) that swept through university geography departments in the USA and British Commonwealth nations. It is exemplified by Paul Williams' very important spatial analyses of dolines, etc. in New Guinea (Williams 1971, 1972a), my studies of Mendip dolines by quadrat analysis (Drake and Ford 1972), and others that soon followed. Williams and I and others had applied Schwarczenbach titration with strict water sampling protocols to place quantitative dissolution studies on a firm footing as well (e.g. Williams 1968 in Ireland, Ford 1971 in the Canadian Rocky Mountains).

In a 1968 paper Panoš and Štelcl (Czechoslovakia) emphasised the need to understand bedrock lithology and geologic structure before interpreting development of tropical karst landforms such as mogotes and I did the same for understanding cave genesis. This began to bring geography-based geomorphologists together with geology-based limestone depositional and diagenesis specialists for the first time.

Until the 1970s geologists largely ignored groundwater - it was not considered to be a 'serious science' like igneous petrology, for example. But demand for groundwater resources was growing, so general hydrogeology can be said to have been born in selected geology departments in North America and Britain during this decade. Some hydrogeologists began to specialize in karst waters but, unfortunately, the distinctive features of karst hydrogeology (cave conduit flow to point-located springs) were not recognized by the majority, who applied the simplistic Darcy flow models worked out for sands to local as well as regional karst flow. 
The arrival of efficient and cheap computing in the late 1970s-early 1980s greatly stimulated quantitative modeling of, first, processes, and then evolving forms. US-based studies by Plummer and colleagues (e.g. Plummer, Wigley, Parkhurst 1978) advanced our understanding of dissolution processes and their rate controls substantially. G.A.Brook (in a $1976 \mathrm{PhD}$ thesis with me) attempted to model the development of doline terrains. The most important worker, though, was Prof. Wolfgang Dreybrodt (Physics, University of Bremen) who from the late '70s onwards began to model both the processes of karst development (limestone dissolution and calcite precipitation) and the forms such as patterns of cave passages that karst features take as a result of the work of these processes. With some outstanding students such as Buhmann, Gabrovšek and Romanov he has contributed greatly to understanding some of the nature and limits of karst evolution. Ahnert and Williams in the late 1990s also introduced new model concepts when they returned to Brook's doline models and made them more sophisticated and realistic in outcome.

Another milestone for scientists in the West was the opening up of nations and research in eastern Europe and the former Soviet Union throughout the 1980s. Both sides of the old "Iron Curtain' learned a lot very quickly, I believe. As important was the appearance of Chinese karst scholars and engineers at international meetings, and the invitations that they gave to visit their great karstlands, the finest in the world. By 1995 I believe it true to state that all important karst research around the world was available to those who took the trouble to seek it. The Internet has since made exchange of ideas and studies, etc. much easier, of course.

A final milestone I would emphasise is the integration of karst terrain engineering specialists into general karst studies. The Chinese have their major focus on applied work, especially for water supply management. Books by the civil engineers Petar Milanović, Borivoje Mijatović and Ognjen Bonacci, based on their considerable and varied experience with problems in the Dinaric karsts have had big impacts, especially elsewhere in Europe. In North America, a series of applied symposia with published Proceedings organized by Barry Beck of the former Florida Sinkhole Research Institute has produced a large quantity of valuable findings on the stability and fragility of karst terrains, especially regarding sinkholes and water quality.

\section{KARSTOLOGY TODAY}

Few month ago has been published a new edition of your and Williams's monograph Karst Hydrogeol- ogy \& Geomorphology, which few reviewers see as the Bible of karst studies. So, you are the right person for this question: what is karstology today, a century after its establishing?

FORD: Thank you for your kind remarks about Karst Hydrogeology and Geomorphology. When writing it Paul Williams and I deliberately attempted to illustrate past and present karst work with studies from as many countries as possible, and as many different sub-specialties. Of course, the amount of work being published these days (in the English language alone) is too great for just two persons to absorb and give fair summaries, but we tried our best.

From my remarks in the previous section, I believe that karstology today is a well defined subject of scientific study that is very well integrated within itself. The leading workers trained in geography, geology, engineering, physics, all know and meet each other regularly. Big karst-focused international symposia such as those of SAZU in Slovenia or the 2005 meeting that Petar Milanović organized in Belgrade are examples in Europe.

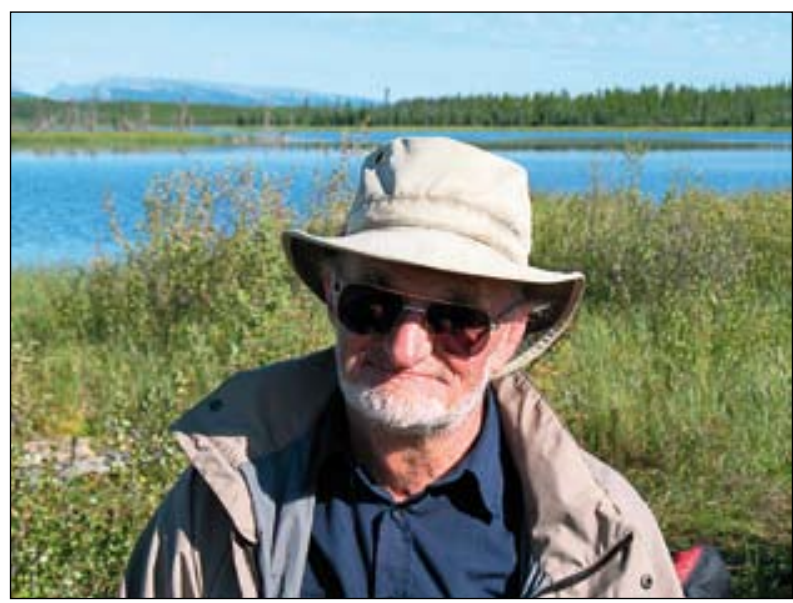

Derek Ford portrait while waiting for a helicopter by a lake in the Mackenzie Mountains, Northwest Territories of Canada. (Photo: archive of D. Ford)

In regard with that, how would you categorised systematic position of karstology as science? As I sow, only an article menaged detailed on that (Panoš 1995) and see it as "an independent integrated scientific system of individual branches that take up complex studies of regions underlain with rock being variably soluble by water". It seems that similar systems as vulkanology or oceanography done more on it.

FORD: You are correct in your opinion, I believe. Karst is comparable in its scope and significance to volcanology (and in the amount of geographic area involved) but is not as great in scope as oceanography. The 
volcanologists have obtained more publicity that karst scientists, perhaps because an exploding volcano is more spectacular.

What is the social status of karstology as science? Do karstologists get awards and honors as others do?

FORD: You have put your finger on our big weakness here. Karst physicists, geologists, geographers, engineers, etc, understand each other well now and work together effectively - BUT karstology remains poorly appreciated by others outside of it. Most geologists, for example, will learn nothing of karstology during their undergraduate training. The majority of hydrogeologists are so ignorant of the enormous differences between standard hydrogeologic behaviour and that in maturely developed karst aquifers that they make many big mistakes in their attempts to predict or model groundwater flow. Urban planners and developers know little or nothing of the subject, either, so that much building of industrial, commercial and private housing on karst terrains is wasteful and/or dangerous.

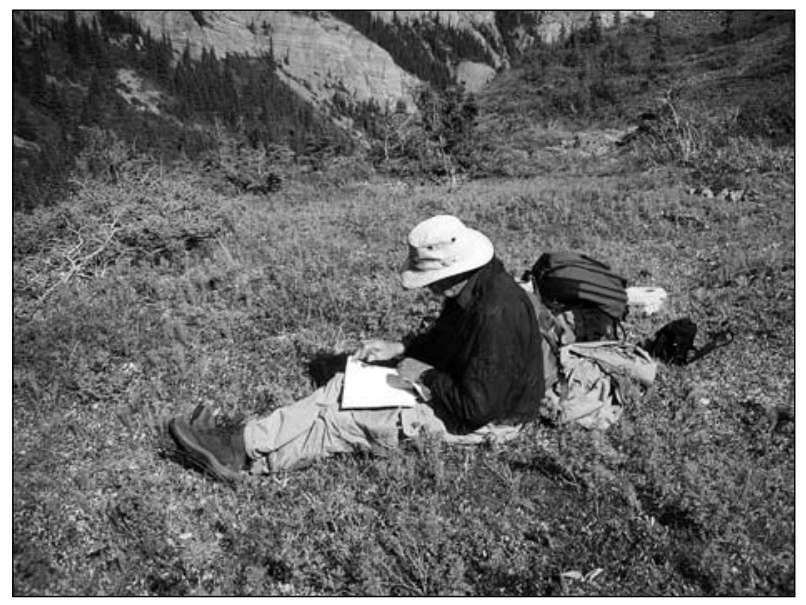

Derek Ford writing up notes in a karst canyon while waiting for a helicopter by a lake both in the Mackenzie Mountains, Northwest Territories of Canada, in August 1976. (Photo: archive of D. Ford)

As a consequence of the lack of understanding of karstology by science and engineering in general, karstologists do not receive the awards, etc. that are commonplace in other fields. A few of us have been elected to our national academies of science (e.g. Yuan Daoxian and Lu Yaoru in China, and myself in Canada) but brilliant achievers such as Prof Dreybrodt have received little or no recognition in their home countries.

What you say on idea to establish karstology association?

FORD: There is the International Speleological Union for cave science, commissions or working groups in the International Geographical Union and the Inter- national Union of Geological Sciences. Karst affairs are now very prominent in the International Union for the Conservation of Nature and in UNESCO World Heritage nominations. There are many specialist symposia around the world e.g. I am invited seven different meetings between February and July this year - impossible to attend all, and much too expensive of course.

The idea of an "umbrella" karst association (i.e. one that covers all of the different interest groups and approaches to karst) had not occurred to me before. It may have some merit - but it is difficult to see how it could be funded, given that all of the groups listed above are looking for money for karst studies.

What is the most appropriate definition of karst today? What is karst today?

FORD: Paul Williams and I (2007 book) define karst as "comprising terrain with distinctive hydrology and landforms that arise from a combination of high rock solubility and well developed secondary (fracture) porosity. Such areas are characterized by sinking streams, caves, enclosed depressions, fluted rock outcrops, and large springs."

Some scholars like Elery Hamilton-Smith follow more widely aproach of Yuan Daoxian and see karst as complex, dynamic and interactive system of incorporating component landforms as well as life, energy, water, gases, soils and bedrock. Is it more closed to mainstream or to margine of karstology today?

FORD: I think it definition is wider than that of Paul and me because we were interested only in describing the physicochemical system. Daoxian / Elery's definitions are valid for the pruposed that they use them for.

How does the world map of karst look like nowadays?

FORD: There is not yet a comprehensive world map of karst, only maps of the distribution of the most suitable karst rocks, such as Figure 1.1 in Ford \& Williams 2007. Emily Hollingworth [ehollin@uark.edu] of the Geology Department, University of Arkansas, is attempting to compile a global register of karst features, terrains and their locations.

What is karstology biggest interest today, what does karstology see as the most important target today? What is its biggest problem?

FORD: Different karst specialists today will have differing chief interests or areas of particular focus; e.g. sinkhole engineers do not have the same interest as students of karren landforms. I believe that this is appropriate because karstology is now too big a scientific subject area to have a single principal goal. My own 'biggest problem' would be the accurate prediction of the patterns of solution conduits in unexplored/unexplorable karst aquifers and the control that those patterns exert upon the rates of 
recharge and discharge of the aquifers, i.e. optimal management of the water resources of karst aquifers.

Karstology face the imperative problem to embrace a much more holistic picture of karst and to synthesize the work of many different disciplines. Often karstology turned to (natural) sciences, in many cases exclusively, and omitted the social and humanistic research. I know personally many speleologists, geologists, geomorphologists and hydrogeologists who have never been interested for results in other disciplines to reach a more complex picture of karst. So, even the excellent, symposium Time in karst in Postojna, has shown that maybe some geologist have not so much interest for karst biology and vice versa biologist for geology. How karstology can ensure a wide picture of karst?

FORD: This is a very good point that you have made. In my listing of the impressive integration that has occurred between different disciplines contributing to karstology during the past 30 years you will note that the biosciences and social sciences are largely absent. For me the Time in Karst symposium was outstanding because of the contribution of Boris Sket and some other cave biologists to it. For the future, then, the International Speleological Union meetings and big international symposia such as the SAZU meetings should attempt to introduce more of these integrative topical sessions. In particular, we need to hear more from the few social scientists working specifically on karst-associated problems. Kazuko Yoshino-Urushibara in Japan is especially interested in this, and an 'impacts' symposium I edited for Environmental Geology 21(3) 1993, and Ford \& Williams 2007, Chapters 11 and 12 emphasize the need and provide examples.

Which regional centers seem to you most productive and most looking forward in karstology?

FORD: To answer this may not make me many friends?? Most regional centers in the past and at present rely on the enthusiasm and competence of just one (or at most 2-3) persons. I suggest we should think of 'schools' rather than buildings with special labs and offices in most countries. Thus I created an influential 'school' with my graduate students at McMaster University from the late 1960s until about $2000 \mathrm{AD}$. Will White had another at Penn State University, USA. In Europe the most prominent school of this kind is that of Prof Dreybrodt, based in Bremen. Another effective form of 'center' is the dispersed institute such as the Karst Waters Institute of America, which has no real physical labs or offices but consists of many individuals collaborating to organize important symposia at different places. Alexander Klimchouk (Ukraine) has taken the lead in organizing a Web-based institute and regular publications

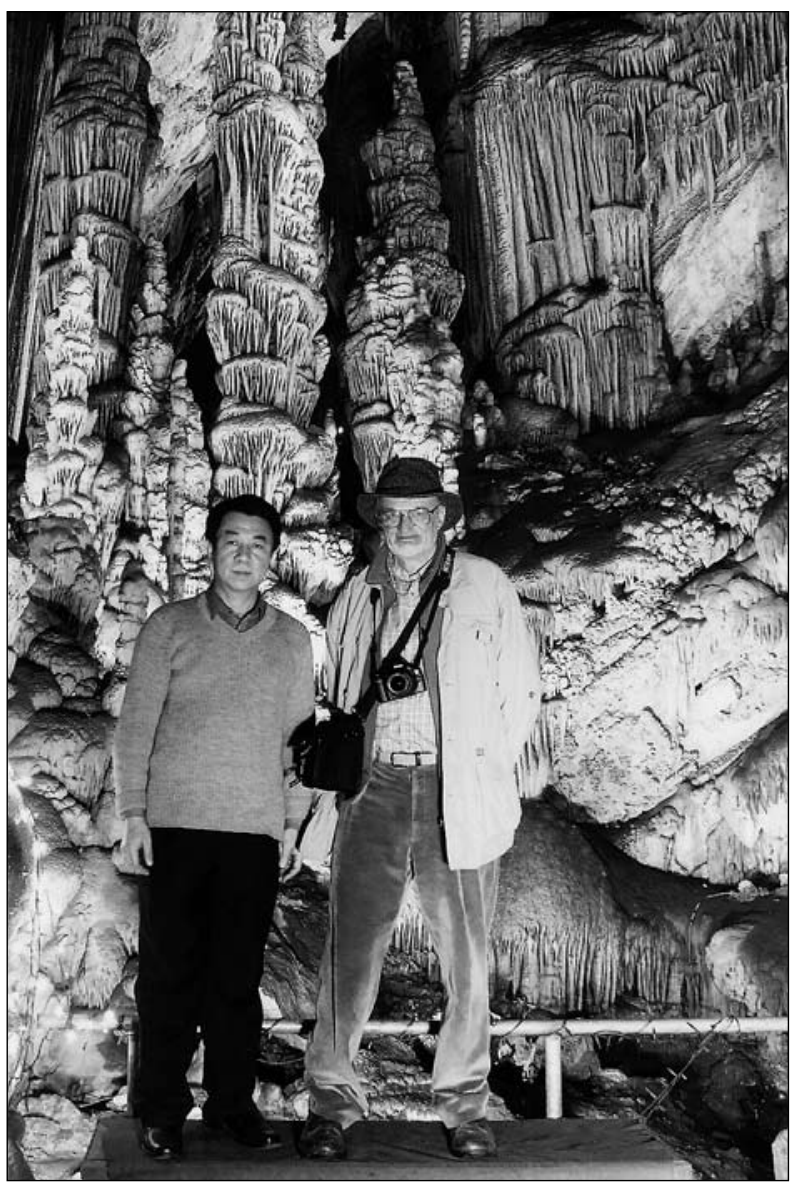

Derek Ford with the cave manager in Shihua Cave, a show cave near Beijing in November 2007. (Photo: archive of D. Ford)

in speleology, which is probably the way of the future for many karstologists.

Centers dedicated to karst or with that as a major focus and having actual offices, labs and budgets for administration that impress me today include SAZU (Slovenia), the hydrogeology group at the University of Tübingen (Germany), the Guilin Institute (China). A new group is forming at the University of Southern Florida and there is a diversified group at the University of Western Kentucky. I do not claim to know all of the active institutes today, however.

\section{DINARIC KARST}

Dinaric karst is recognized as the born place of karstology. How do you see the role of Dinaric karst in karstology today? Which research centers in Dinarides have karstology abilities to resolve contemporary problems of karst? With which colleague from Dinaric karst do you have productive and uninterrupted cooperation? Which are the types of information originated from Dinaric karst nowadays? 
FORD: All karstologists must see two principal karst areas before they die - the Dinaric karst and the South China karst. These are the classic and definitive type areas. The Dinaric karst is very important for its practical successes achieved in water management, dam building, etc. in which it continues to lead the world; Bosnia-Herzegovina, Croatia, Serbia and Slovenia have all made important contributions here and I look forward to their making many more. The Dinaric karst is also extremely important because it is a repository of immense quantities of paleoenvironmental data contained in its polje, sinkhole and cave infillings. In the future they should contribute much more to our understanding of tectonic and general landform evolution in tectonically active terrains.

The break up of former Yugoslavia caused many unfortunate interruptions in the development of karstology and the practice of individuals in the Dinaric region, as we know. I have been able to maintain more or less uninterrupted collaborations or correspondence with SAZU and with Professor Milanović. I look forward to much wider acquaintance in the future.

\section{PUBLICATIONS AND POPULARIZATION}

I found that people living in karst areas usually simply think that they know everything about karst. In fact, it is a big misunderstanding. How much does karstology take care about this kind of problems and how much does it tend to go behind boundary of its discipline? How much karstology invest in its popularization? It seems very important because researches budgets depend on public perception of sciences.

FORD: Karstologists have been successful in integrating their efforts across the engineering, geography, geomorphology, geology and speleology boundaries, as I wrote above. I agree that they need to become more active in interesting the general public and politicians in many countries (some are all too well aware of practical karst problems and have special legislation to control them, e.g. Slovenia, Florida, Yucatan, West Rand; I have worked hard in Ontario, etc).

What should be stressed about karst outside the kastologists circle, what would noticeable show the importance of karst?

FORD: The practical matters of water supply and management, avoidance of pollution. The practical matters of avoiding catastrophic sinkhole formation resulting from new urban developments, and problems of water supply dam construction and maintenance on karst. The protection or repair/re-installing of the specialized ecosystems found on many karst terrains (alvars on glaciated surfaces are important special ecosystems in my part of Canada for example). The cultural im- portance of karst must always be emphasized - the circum-Mediterranean role of limestone topography and limestone buildings is one of the gems of global cultural landscapes, I would say it is a prime example. The combination of karst topography with wet rice agriculture in southern China, Vietnam and islands of the Philippines is another. Recent efforts by individual nations and some of we karstologists have led to strong recognition of karst topography and particular caves on the UNESCO World Heritage list of sites, which is promising.

Karst perception finally depends on productions of holistic karstology works, which would be the source for popularization activities. There is only one monograph about Dinaric karst as total region (by Jean Nicod), and two monographs which focuses on Slovenian Kras (by Ivan Gams and Andrej Kranjc ed.). How do other karst regions in the world manage with this kind of problem? How is preceding the idea to publish a world karst atlas or a world monograph on karst?

FORD: For major books, please see (1) the bibliography in Ford \& Williams 2007. Karst Hydrogeology and Geomorphology. Chichester: John Wiley \& Sons, Ltd. xiii, $563 \mathrm{p}$. This is a very long list of topical and regional references.

(2) John Gunn (Editor) 2004 Encyclopedia of Caves and Karst Science. New York, Fitzroy Dearborn, (902 pges) is an excellent text that covers most standard topics in physical cave and karst science, and in cave bioscience. It has summaries of the nature and geography of karst in most of the major karst regions, written by regional specialists. It is the most comprehensive global outline of karst phenomena yet published.

(3) Klimchouk,A.V., Ford, D.C., Palmer, A.N. and Dreybrodt,W. (Editors). 2000. Speleogenesis; Evolution of Karst Aquifers. Huntsville, Al. National Speleological Society of America, (527 pages) is a systematic review of this subject by many experts. It describes many different caves of the world.

(4) Bosak, P., D.C. Ford, Glazek, J. and Horacek, M. (Editors.) 1989 Paleokarst: a world regional and systematic review. Elsevier/Academia, Amsterdam and Prague, (720 pages) has a great deal of world regional material on paleokarst, as the title implies. It is now out of date for many geographical regions, but remains an important systematic source.

(5) as noted, Emily Hollingworth of the University of Arkansas is attempting to compile a world atlas and gazetteer of caves and karst areas.

Interview has been done by e-mail at the end of 2007 and beginning of 2008. Thanks to college Simone Milanolo for the assistance.

Ivo Lučić 